\title{
Changes in gene expression patterns associated with microspore embryogenesis in hexaploid triticale ( $\times$ Triticosecale Wittm.)
}

\author{
I. Żur • E. Dubas • M. Krzewska • R. A. Sánchez-Díaz • \\ A. M. Castillo • M. P. Vallés
}

Received: 31 July 2013/Accepted: 24 October 2013/Published online: 9 November 2013

(c) The Author(s) 2013. This article is published with open access at Springerlink.com

\begin{abstract}
To gain a better understanding of the molecular mechanisms controlling microspore embryogenesis (ME) in triticale ( $\times$ Triticosecale Wittm.), the expression patterns of 13 genes, previously identified in bread wheat to be associated with microspore-derived embryo development, were analysed. Four triticale doubled haploid (DH) lines, significantly different with respect to embryogenic potential, were studied. The gene expression profile was dissected at different points of the ME induction procedure up to the 8 th day of in vitro culture (dc). RT-PCR revealed that these 13 genes were expressed during triticale ME. Variations in gene expression profiles were observed between the studied DH lines. DH28 (highly embryogenic) was the only one in which all analysed genes (Ta.TPDIlike, TAA1b, GSTF2, GSTA2, CHI3, Tad1, XIP-R1, TaAGL14, TaNF-YA7, SERK2, SERK1, TaEXPB4, TaME1) were up-regulated during the first 8dc. In the less embryogenic DH31, TAA1b, GSTA2 and TaEXPB4 were already induced on 4dc. In DH25, ME was initiated quite efficiently but soon inhibited, which coincided with the lack of gene expression (TaEXPB4, TaME1) or downregulation (Tadl, XIP-R1, TaAGL14, TaNF-YA, SERK2, $S E R K 1)$ on $8 \mathrm{dc}$. In the recalcitrant DH50 line, the majority of genes were expressed at a lower level or not at all,
\end{abstract}

I. Żur $(\bowtie) \cdot$ E. Dubas · M. Krzewska

The Franciszek Górski Institute of Plant Physiology, Polish Academy of Sciences, Niezapominajek 21, 30-239 Kraków, Poland

e-mail: zur@ifr-pan.krakow.pl

R. A. Sánchez-Díaz · A. M. Castillo · M. P. Vallés Estación Experimental de Aula Dei, Consejo Superior de Investigaciones Científicas (EEAD-CSIC), Avda Montañana 1005, 50059 Zaragoza, Spain indicating disturbances in ME initiation. In this study, the molecular mechanisms involved in triticale ME induction were analysed for the first time, laying the foundation for further characterisation of specific genes controlling microspore-derived embryo development.

Keywords Androgenesis - Microspore reprogramming · Gene expression · Triticale

\section{Introduction}

Due to its yield potential, good grain quality and high tolerance for environmental conditions, triticale $(\times$ Triticosecale Wittm.) is a very promising crop candidate for modern agricultural systems, especially bio-organic and sustainable farming. The continued growth of the economic importance of this cereal generates a strong interest in its genetics and genome organisation and in biotechnological tools which can be used for its further improvement (Góral et al. 2005; Tams et al. 2005; Alheit et al. 2011; Badea et al. 2011; Tyrka et al. 2011; Krzewska et al. 2012; Żur et al. 2012). Among others, the process termed 'microspore embryogenesis' (ME) or 'androgenesis', as a method for fast production of totally homozygotic, doubled haploid (DH) lines, can significantly accelerate breeding progress.

Since the first report describing anther-derived triticale plant formation (Wang et al. 1973), considerable progress in $\mathrm{DH}$ technology has been made, but great genotype dependency, the rather poor regeneration ability of the produced embryo-like structures (ELS) and a high rate of albino plant formation continue to limit wide application of this technology (Tuvesson et al. 2003). Any improvements that might increase the effectiveness of triticale $\mathrm{DH}$ production would be highly valued, especially by triticale 
breeders for whom the instant production of true breeding lines would bring considerable profits.

It is well known that ME is accompanied by many physiological, metabolomical and molecular changes, but it is very difficult to distinguish those directly involved in embryogenesis induction. Over the past decade many efforts have been undertaken to obtain a better understanding of the mechanisms that induce microspore reprogramming from the gametophytic to the sporophytic pathways. Despite extensive studies, the knowledge concerning the molecular and physiological background behind this switch is still fragmentary. The expression patterns of genes associated with microspore reprogramming have been examined widely in model plant species such as tobacco, rapeseed and barley (for review see Hosp et al. 2007; Soriano et al. 2013). In barley, a number of candidate genes have been identified and associated with ME induced after stress mannitol treatment (Maraschin et al. 2006; Muñoz-Amatriaín et al. 2006, 2009). Also, in wheat, five genes have been identified in microsporederived embryogenic structures, one of them corresponding to an early cysteine-labelled metallothionein (EcMt) (Reynolds and Kitto 1992; Reynolds and Crawford 1996). Recently, a collection of wheat genes induced during microspore-derived embryo development has been expanded and connected to early, middle and late stages of microspore embryogenesis (Sánchez-Díaz et al. 2013).

In order to gain a better understanding of the molecular mechanisms that control triticale ME, the expression profile of wheat orthologous genes controlling intra-embryo communication (Ta.TPDI-like), early cell pattern formation (TaAGL14), cell wall modification (XIP-R1), signalling (TAAIb, SERK1, SERK2), defence reactions (GSTF2, GSTA2, CHI3, Tad1) and embryo differentiation (TaEXPB4, TaNF-YA7, TaME1) were analysed in four triticale $\mathrm{DH}$ lines with different androgenic responses. To our knowledge this is the first study concerning the expression of genes connected with ME in triticale.

\section{Materials and methods}

Plant material

The population of $146 \mathrm{DH}$ lines of winter triticale was derived from the F1 generation of a cross between German inbred line 'Saka 3006' and Polish cv. 'Modus' by the maize method (Wędzony 2003) in the State Plant Breeding Institute, Hohenheim University in Stuttgart (Germany), and kindly provided by Dr. Eva Bauer. Four DH lines selected from this population were used in this study: two high- (DH28 and DH31) and two low-embryogenic (DH25 and DH50). Germinating triticale kernels were vernalised and donor plants were grown as described earlier by Krzewska et al. (2012).

Protocol for ME induction

Tillers with central florets at the mid- to late-uninucleate microspore stage were pre-treated at $4{ }^{\circ} \mathrm{C}$ in the dark for 3 weeks. The protocol for ME induction was described previously by Żur et al. (2009). Collected microspores were re-suspended in a volume of 190-2 medium modified according to Pauk et al. $(2000,2003)$ to produce a final suspension density of 70,000 microspores per $\mathrm{ml}$. The microspore suspensions were co-cultured with immature triticale ovaries ( 10 ovaries per $\mathrm{ml} ; 1.5 \mathrm{ml}$ per $35 \times 10 \mathrm{~mm}$ Petri dish) and incubated in darkness at $26{ }^{\circ} \mathrm{C}$.

Sample collection and cytological analysis

The samples of microspores were directly isolated from freshly-cut tillers (0dp) and low-temperature-treated tillers (21dp) and collected with the use of a Pasteur pipette from Petri dishes after 4 and, finally, after 8 days of in vitro culture $(4 \mathrm{dc}, 8 \mathrm{dc})$.

At the same time points, the course of ME was monitored with the use of a Nikon Eclipse TS100 inverted microscope equipped with Hoffman modulation contrast and a DS-Ril digital camera and processed by Laboratory Imaging Ltd. NIS-Elements AR 2.10 programme (Fig. 1). The percentages of microspores at each stage of development were calculated for the total of 500 objects per analysis. The experiment was based on five biological replicates (each Petri dish containing $1.5 \mathrm{ml}$ of microspore suspension was considered one replicate).

RNA extraction and cDNA synthesis

Total RNA was extracted using TRIzol Reagent (Gibco BRL) and cleaned with an RNeasy MinElute Cleanup kit (Qiagen). cDNA synthesis was performed using an MMLV RT Reverse Transcriptase kit (Promega).

Selection of genes

Genes were selected according to their expression pattern in wheat ME (Sánchez-Díaz et al. 2013). The following genes were analysed: TaAffx.3154.1 (Ta.TPD1-like), Ta.9528.1 (TAA1b), Ta.1775.1 (GSTF2), Ta.303.2 (GSTA2), Ta.21342.1 (CHI3), Ta.28319.1 (Tadl), Ta.13785.1 (XIP-RI), Ta.6411.1 (TaAGL14), Ta.10047.1 (TaNF-YA7), Ta.6832.1 (SERK2), Ta.12817.1 (SERK1), Ta.3749.1 (TaEXPB4) and Ta.7773.1 (Ta.ME1). The 18S ribosomal wheat gene was used as a control. 
Fig. 1 The progressive stages of embryogenesis in isolated microspore cultures of four doubled haploid (DH) lines of triticale $(\times$ Triticosecale Wittm.) of high (DH31, DH28) and low (DH25, DH50) androgenic potential. The morphology of microspores: after 3 weeks of low temperature $\left(4{ }^{\circ} \mathrm{C}\right)$ embryogenesis-inducing treatment (21dp); after 4 days of in vitro culture $(4 d c)$; and after 8 days of in vitro culture $(8 d c)$. Hoffman contrast, bars $20 \mu \mathrm{m}$

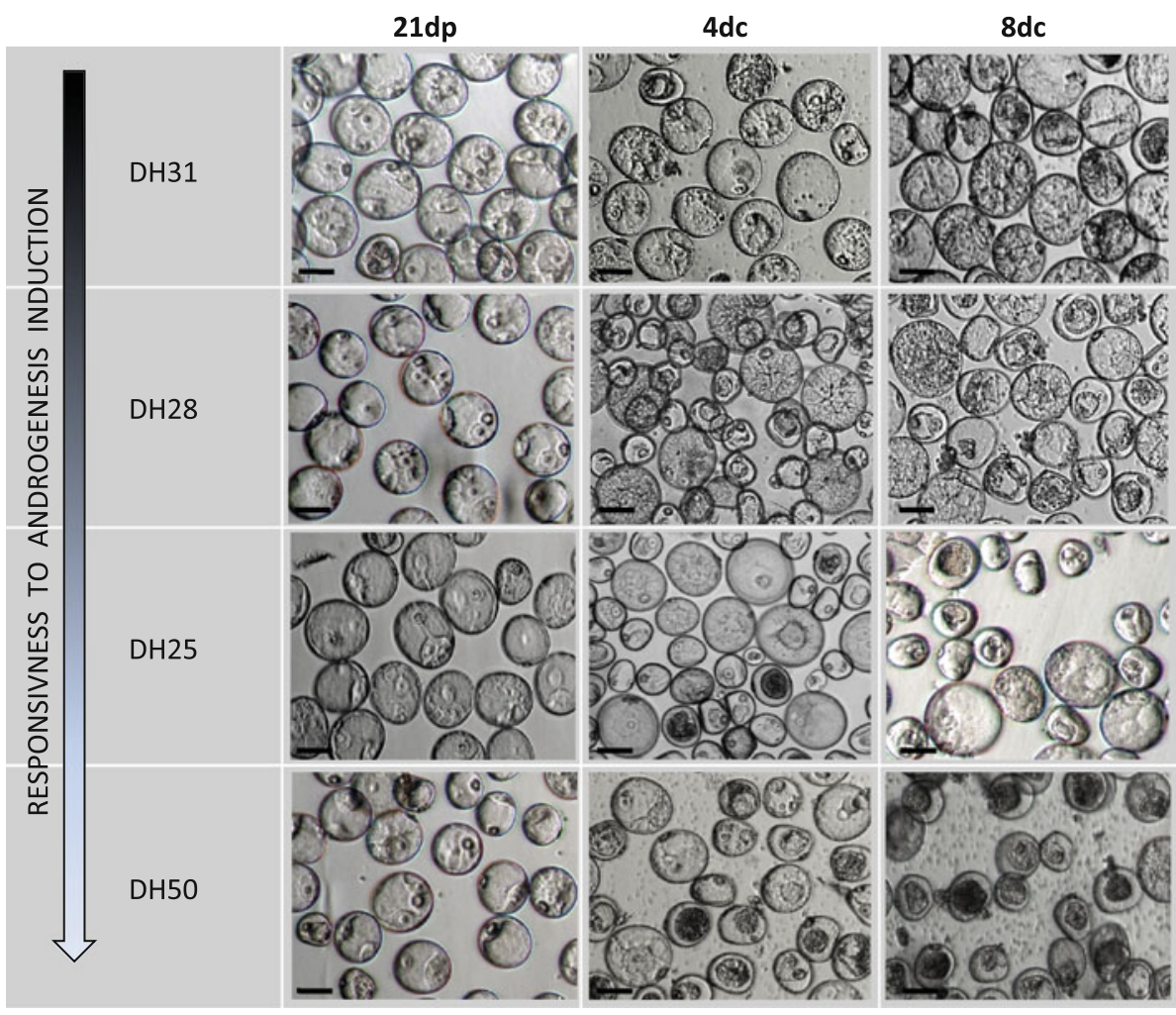

Table 1 PCR primer sequence and annealing temperature for semiquantitative RT-PCR

\begin{tabular}{lll}
\hline Unigen & Forward 5'-3' & Reverse 5'-3' \\
\hline TaAff .3154 .1 & AAGTTTCAGCGTCTTCCTCGCT & TCGATGCAGGTGTTGGTGAACT \\
Ta.9528.1 & TGCTCTCCATCCTCTGTTGC & GGGATGTGGACCTTGAAGAAGT \\
Ta.1775.1 & CGGCAAAGCTGACGAATCTGTT & ACTTCTCTGCCTTCTTTCCGAACC \\
Ta.303.2 & GCGGAATCGAAGAATTAGCAATGG & AAGGTGAACGGGATGTGGTT \\
Ta.21342.1 & TTCAAGACGGCGTTGTGGTTCT & TGGTTGTAGCAGTCCAGGTTGT \\
Ta.28319.1 & AACGCCTTCTACCAGGTCCCTT & ACGTTGGTGAACTGGCTCGTGTT \\
Ta.13785.1 & GGCTCTGGAACTTCAACAAGGACT & TTTGGGTGAACGTAACCGACCT \\
Ta.6411.1 & AAGCTGAGCGCTACGGCCTA & CACGAATTGTCCCATTGACG \\
Ta.10047.1 & AGGCAAGATGATGTCGGCTTTG & GCATGGTATTGCTTCGCGTTCA \\
Ta.6832.1 & AGCTTCGATTCCTCCGTCTT & AGGCACCTGCTGATTGAGTT \\
Ta.12817.1 & AACTGTCAGGTGCATTGGTGTC & 58 \\
Ta.3749.1 & GGCTACAAGCACACTAACCAGT & TCCAGAACTTGGAGGGTGCTAA \\
Ta.7773.1 & ACCAAAGCTCGTGTGATGAGGA & TTGCATGGCACCCTTTGGAA \\
$18 S$ rDNA & CGGCTACCACATCCAAGGAA & TTCGTTGAGGAAGGCCCAGTT \\
\hline
\end{tabular}

Expression analysis by RT-PCR

Standard RT-PCRs were performed using samples and primers indicated in Table 1. Primer pairs were designed based on the wheat gene consensus sequence on HarvEST:Wheat version 1.59 (Sánchez-Díaz et al. 2013). The PCR conditions were as follows: $94{ }^{\circ} \mathrm{C}$ for $2 \mathrm{~min}$ and 35 cycles at $94{ }^{\circ} \mathrm{C}$ for $60 \mathrm{~s}, 55-60{ }^{\circ} \mathrm{C}$ (depending on primers) for $60 \mathrm{~s}, 72{ }^{\circ} \mathrm{C}$ for $60 \mathrm{~s}$, and $72{ }^{\circ} \mathrm{C}$ for $10 \mathrm{~min}$ using $190 \mathrm{ng}$ of template cDNA. Fragments were visualised by agarose gel electrophoresis with SYBR staining (Invitrogen).

\section{Results and discussion}

The progress in the course of ME in suspension cultures of the examined triticale DH lines and final effectiveness of the process is presented in Table 2 and Fig. 1. 
Table 2 The progress in the course of microspore embryogenesis and the final effectiveness of the process in four DH lines of triticale $(\times$ Triticosecale Wittm.)

\begin{tabular}{lcccc}
\hline & DH25 & DH50 & DH31 & DH28 \\
\hline $\begin{array}{l}\text { \% Embryogenic microspores at } \\
\text { 21dp* }\end{array}$ & 13.0 & 3.4 & 19.1 & 18.4 \\
$\begin{array}{l}\text { \% Embryogenic microspores at } \\
\text { 4dc** }\end{array}$ & 9.5 & 4.4 & 18.5 & 15.7 \\
$\begin{array}{l}\text { \% Embryogenic microspores at } \\
\text { 8dc*** }\end{array}$ & 2.2 & 4.2 & 17.0 & 9.4 \\
Final effectiveness of ME & & & & \\
ELS/10 MCS & 4.4 & 21.0 & 139.8 & 146.5 \\
R/10 5 MCS & 0.6 & 1.0 & 19.3 & 32.0 \\
GR/10 $10^{5}$ MCS & 0.6 & 0 & 17.4 & 31.4 \\
\hline
\end{tabular}

The percentages of microspores at each stage of development were calculated for the total 500 objects per analysis. The experiment was based on five biological replicates (each Petri dish containing $1.5 \mathrm{ml}$ of microspore suspension was considered one replicate)

$21 \mathrm{dp} *$-microspores isolated from low temperature-treated tillers (21 days at $4{ }^{\circ} \mathrm{C}$ ); embryogenic microspores include star-like structures (SLSs)

$4 \mathrm{dc} * *$-microspores collected after 4 days of in vitro culture; embryogenic microspores include SLSs and microspores after symmetrical division of the nucleus

$8 \mathrm{dc} * * *$-microspores collected after 8 days of in vitro culture; embryogenic microspores include SLSs, microspores after symmetrical division of the nucleus and multicellular structures

ELS $/ 10^{5}$ MCS - androgenic structures produced per $10^{5}$ microspores $\mathrm{R} / 10^{5} \mathrm{MCS}$ - total number of regenerated plants per $10^{5}$ microspores $\mathrm{GR} / 10^{5} \mathrm{MCS}$ - the number of green plants regenerated per $10^{5}$ microspores

The RT-PCR assay revealed that primer sets designed for genes induced during bread wheat anther culture turned out to be homologous to the triticale cDNA sequence. Differences between DH lines in the level and the pattern of expression were observed in all genes studied and are presented in Fig. 2. Genes identified as induced at 5 days of culture in wheat, namely TaTPD1-like, TAAlb, GSTF2 and GSTA2 (Sánchez-Díaz et al. 2013), were also activated in triticale at the corresponding phase of sporophytic development (4-8dc). Of these four genes, only the glutathione $S$-transferase gene GSTF2 was induced on $4 \mathrm{dc}$ in all studied genotypes. However, differences in expression profile were observed, showing the highest level on $4 \mathrm{dc}$ in the low-responding lines (DH25 and DH50) and the highest or equal level on 8dc in the high-responding lines DH28 and DH31, respectively. The other induced GST (GSTA) presented the same pattern of expression in all lines except DH28, in which it was specifically expressed on 8dc. For the first time, Vrinten et al. (1999) identified GST transcripts in mannitol-treated barley microspores in the early stages of embryogenesis, although its expression was not associated with the acquisition of embryogenic potential.
The up-regulation of GST genes after stress treatment has also been observed in barley by Maraschin et al. (2006), Muñoz-Amatriaín et al. $(2006,2009)$ and Jacquard et al. (2009). In triticale, their induction after stress treatment was observed for GSTA as previously described in wheat (Sánchez-Díaz et al. 2013) and also for GSTF2. It seems that high expression of GSTs is especially important starting on the 8th day of in vitro culture, which may be associated with the first multicellular structure formation. It might be supposed that GSTs, the enzymes that catalyse the conjugation of glutathione (GSH) to a wide variety of substrates and can also act as GSH-dependent peroxidase, play an important role in further phases of androgenic structure development. Such a conclusion seems to be confirmed by Gong et al. (2005), who showed that GST expression determined in vitro shoot regeneration from leaf explants of transgenic Arabidopsis thaliana.

In highly 'responsive' lines, TaTPDI-like was expressed specifically on 4dc in DH28, whereas in DH31 the expression was first observed on $4 \mathrm{dc}$, with the highest level of expression on $8 \mathrm{dc}$. This gene was expressed specifically on $8 \mathrm{dc}$ in DH25 and at a low level on 4dc in DH50. Another gene, TAAlb, was expressed mainly on 8dc; however, in lines DH31 and DH25, it was also expressed at a low level on $4 \mathrm{dc}$. Initially, the functions of both these genes (Ta.TPD1-like and TAAIb) were connected to early anther development. TAPETUM DETERMINANT1 (TPDI) encodes for a small protein that is required for the maintenance of tapetum cell fate (Yang et al. 2003). However, Ta.TPD1-like was also expressed in two-celled proembryos and in wheat embryos excised 10,12 and 14 days after pollination, and a role in intra-embryogenic cell-to-cell communication was recently proposed for it (Leljak-Levanić et al. 2013; Sánchez-Díaz et al. 2013). The TAAlb gene codes for a fatty acil-coA reductase that mediates the biosynthesis of long chains of fatty alcohols (VLCFA) and was expressed within the sporophytic tapetum cells (Wang et al. 2002). The expression profile of TAAlb in both wheat and triticale ME and the high level of expression of this gene in excised zygotic wheat embryos suggested another function which could be related to VLCFA signalling (Worrall et al. 2003; Sánchez-Díaz et al. 2013).

Genes characterised previously as middle or late ME genes in wheat were also induced in triticale at the moment of multicellular structure formation (8dc). These genes showed major differences in the expression pattern between lines. Three of them, CHI3, Tadl and XIP-R1, have been associated with stress-induced responses.

In planta, chitinases play an important role inducing defence reactions and in plant growth and development e.g. in zygotic and somatic embryogenesis (review in Grover 2012). In triticale microspore cultures, the expression pattern of the $\mathrm{CHI} 3$ gene was highly genotype-specific and 


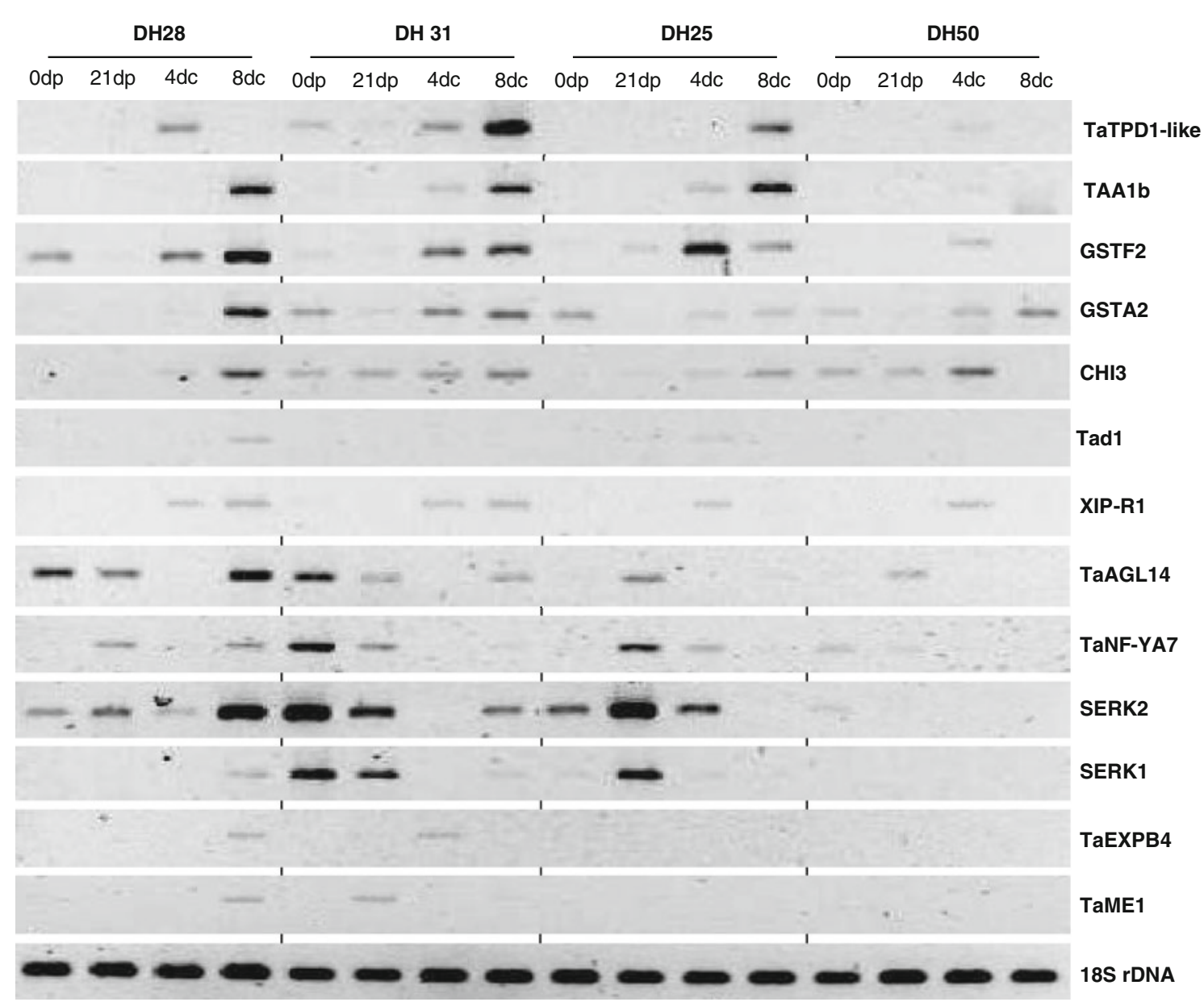

Fig. 2 Expression analyses by semiquantitative RT-PCR of thirteen genes associated with microspore embryogenesis in triticale. Four different stages were assayed in each of the four lines $(\mathrm{DH} 28, \mathrm{DH} 31$, DH25 and DH50): uni-nucleated microspores before stress treatment

inconsistent. Only in the highly responding DH28 was this gene specifically expressed on 8dc. In wheat, $\mathrm{CHI} 3$ was highly induced in the anther culture phase but its expression was also inconsistent between cultivars, being almost constitutive in the low-responding one.

Although Tadl induction was reported earlier in seedlings treated with low temperature (Koike et al. 2002), in this experiment no expression was observed in cold-treated triticale microspores. Instead, Tadl was expressed in in vitro cultured microspores, on $4 \mathrm{dc}$ or $8 \mathrm{dc}$, but only in lines DH25 and DH28, respectively. It coded for a protein that showed a certain similarity to plant defensins or $\delta$ thionins, small cysteine-rich proteins that play important roles in plant defence against pathogenic fungi (Koike et al. 2002).

Next in this group, $X I P-R I$ can be considered an early gene in triticale, as its expression on $4 \mathrm{dc}$ was observed in all studied DH lines. Depending on its embryogenic potential, this gene was up- or down-regulated on $8 \mathrm{dc}$. XIP$R l$ is involved in the degradation of arabinoxylans (AXs),
$(O d p)$, microspores after 21 days of low temperature treatment (21dp), microspores after 4 days of in vitro culture $(4 d c)$, and microspores after 8 days of in vitro culture $(8 d c)$. $18 \mathrm{~S}$ rDNA was used as a control

the main non-starch polysaccharides from grain cell walls (Dornez et al. 2010). In wheat, a near-specific expression in ME was observed in Tadl and XIP-R (Sánchez-Díaz et al. 2013).

In highly-responding lines DH28 and DH31, a group of genes associated with developmental control, namely $T a$ AGL14, TaNF-YA7, SERK2 and SERK1, was induced on $8 \mathrm{dc}$. These genes were also expressed in uni-nucleated microspores of DH31 and two of them (TaAGL14, SERK2) in DH28. However, the level of expression in the majority of these genes decreased after the stress treatment. Moreover, these genes were not expressed during culture in the recalcitrant DH50 line and were down-regulated on $8 \mathrm{dc}$ in DH25, which was associated with inhibited ME. Different developmental programs are represented by these genes: TaAGL14 is a MADS-box type II (MIKC-type) gene (Zhao et al. 2006) which controls determination of cell identity in plants (Masiero et al. 2011 and references therein); TaNF$Y A 7$ is a nuclear factor that binds to the CCAAT-box element(s) (Stephenson et al. 2007) as the Arabidopsis LEAFY 
COTYLEDON1 (LEC1) gene, one of the major regulators of embryogenesis (Harada 1999, and references therein); SERK proteins are involved in signalling pathways associated with cell pluripotency and reprogramming (Hecht et al. 2001). In many plant species their expression has been associated with the early stages of zygotic and somatic embryogenesis (Savona et al. 2012, and references therein). In highly-responding cultivars of wheat, SERK1 and SERK2 were expressed only before the stress treatment (Sánchez-Díaz et al. 2013).

A low expression level of TaEXPB4 and TaME1, identified in wheat as associated with late phases of ME, was observed only in the highly 'responsive' DH lines of triticale. In wheat, a role for TaEXPB4 in cell extensibility associated with active growth at the globular phase of embryo development was proposed by Sánchez-Díaz et al. (2013). The low level of expression of this gene in triticale may be due to the lower demand of cell extensibility, since the structures on 4-8dc are still confined inside the exine. The expression of gene TaME1 (MICROSPORE EMBRYOGENESIS-1) was first observed in the work of Sánchez-Díaz et al. (2013). In wheat, it was identified and characterised as an embryo-specific gene, whereas its expression in triticale was observed on 21dp in DH31 and on 8dc in DH28. None of these genes was expressed at any stage of microspore development in the recalcitrant lines (DH25 and DH50).

In attempting to associate gene expression profiles, cytological observations of the ME process and final plant production efficiency, it should be remembered that final ME efficiency is also modulated by later events along the developmental pathway. For example, proper exine rupture and successful release of multicellular structure are very important for the final efficiency of the process. Considering this, DH28, the line with the highest final androgenesis efficiency, is the only one in which all genes were expressed during the microspore culture phase. In line DH31, several genes were expressed earlier than in the other DH lines, confirming morphological observations indicating faster initiation of ME. The differences in gene expression between these lines suggest that DH28 possesses a more precise early signalling regulation (TaTPD1-like). Moreover, DH31 was characterised by lower activation of genes related to cell identity and embryogenesis (TaAGL14, TaNF-YA7 and SERK2). Altogether, this can result in lower final efficiency of ME. The gene expression pattern in line $\mathrm{DH} 25$ also seems to be in agreement with the morphological characterisation of this genotype, indicating a high induction rate on $4 \mathrm{dc}$ and severe disturbances in ME progress on 8dc. Finally, in line DH50, the analysed genes were not expressed or expressed at very low levels, indicating that initiation of ME was faulty from the beginning.
The morphological characterisation of isolated microspore cultures of four DH lines with different rates of $\mathrm{ME}$ induction, together with the description of expression profile of genes related to mechanisms such as signalling, cell fate determination, and cell wall modification, enabled the first step in identification of the molecular mechanisms involved in triticale ME induction. These results confirm that despite different procedures used for triticale and wheat microspore reprogramming (cold vs. mannitol stress treatment) and various androgenesis methods (isolated microspore vs anther culture) at least some molecular mechanisms are the same. The obtained results should be considered as preliminary and the presented study should be seen as the starting point for further characterisation of genes associated with androgenesis induction in triticale.

Acknowledgments The seeds of triticale DH lines were kindly provided by Dr. Eva Bauer from the State Plant Breeding Institute, Hohenheim University, Germany. The work was supported by Project AGL2010-17509 from 'Plan Nacional de Recursos y Tecnologías Agroalimentarias' of Spain, the Bilateral Project CSIC (Spain)-PAS (Poland) 2010PL0006 and by COST Action FA0903 'Harnessing of Reproduction for Plant Improvement' (HAPRECI). Dr. Ewa Dubas was the recipient of a STSM fellowship from COST Action FA0903 'Harnessing of Reproduction for Plant Improvement'. RA Sánchez-Díaz was the recipient of a predoctoral fellowship, from Junta Ampliación de Estudios, Consejo Superior de Investigaciones Científicas (JAE-CSIC) of Spain.

Open Access This article is distributed under the terms of the Creative Commons Attribution License which permits any use, distribution, and reproduction in any medium, provided the original author(s) and the source are credited.

\section{References}

Alheit KW, Reif JC, Maurer HP, Hahn V, Weissmann EA, Miedaner T, Würschum Y (2011) Detection of segregation distortion loci in triticale ( $\times$ Triticosecale Wittmack) based on a high-density DArT marker consensus genetic linkage map. BMC Genomics 12:380-393

Badea A, Eudes F, Salmon D, Tuvesson S, Vroljik A, Larsson CT, Caig V, Huttner E, Kilian A, Laroche A (2011) Development and assessment of DArT markers in triticale. Theor Appl Genet 122:1547-1560

Dornez E, Croes E, Gebruers K, De Coninck B, Cammue BPA, Delcour JA, Courtin CM (2010) Accumulated evidence substantiates a role for three classes of wheat xylanase inhibitors in plant defense. Crit Rev Plant Sci 29:244-264

Gong H, Jiao Y, Hu W-W, Pua E-C (2005) Expression of glutathioneS-transferase and its role in plant growth and development in vivo and shoot morphogenesis in vitro. Plant Mol Biol 57:53-66

Góral H, Tyrka M, Spiss L (2005) Assessing genetic variation to predict the breeding value of winter triticale cultivars and lines. J Appl Genet 46:125-131

Grover A (2012) Plant chitinases: genetic diversity and physiological roles. Crit Rev Plant Sci 31:57-73

Harada JJ (1999) Signalling in plant embryogenesis. Curr Opin Plant Biol 2:23-27 
Hecht V, Vielle-Calzada JP, Hartog MV, Schmidt ED, Boutilier K, Grossniklaus U, de Vries SC (2001) The Arabidopsis SOMATIC EMBRYOGENESIS RECEPTOR KINASE 1 gene is expressed in developing ovules and embryos and enhances embryogenic competence in culture. Plant Physiol 127:803-816

Hosp J, Maraschin SF, Touraev A, Boutilier K (2007) Functional genomics of microspore embryogenesis. Euphytica 158:275-285

Jacquard C, Mazeyrat-Gourbeyre F, Devaux P, Boutilier K, Baillieul F, Clément C (2009) Microspore embryogenesis in barley: anther pre-treatment stimulates plant defence gene expression. Planta 229:393-402

Koike M, Okamoto T, Tsuda S, Imai R (2002) A novel plant defensinlike gene of winter wheat is specifically induced during cold acclimation. Biochem Biophys Res Commun 298:46-53

Krzewska M, Czyczyło-Mysza I, Dubas E, Gołębiowska-Pikania G, Golemiec E, Stojałowski S, Chrupek M, Żur I (2012) Quantitative trait loci associated with androgenic responsiveness in triticale $(\times$ Triticosecale Wittm.) anther culture. Plant Cell Rep 31:2099-2108

Leljak-Levanić D, Juranić M, Sprunck S (2013) Markers for early zygotic reprogramming in wheat (Triticum aestivum L.) encode small putative secreted peptides and proteins involved in proteasomal degradation. Plant Reprod. doi:10.1007/s00497013-0229-4

Maraschin SF, Caspers M, Potokina E, Wülfert F, Graner A, Spaink HP, Wang M (2006) cDNA array analysis of stress-induced gene expression in barley androgenesis. Physiol Plant 127:535-550

Masiero S, Colombo L, Grini PE, Schnittger A, Katere MM (2011) The emerging importance of type I MADS box transcription factors for plant reproduction. Plant Cell 23:865-872

Muñoz-Amatriaín M, Svensson JT, Castillo A-M, Cistué L, Close TJ, Vallés M-P (2006) Transcriptome analysis of barley anthers: effect of mannitol treatment on microspore embryogenesis. Physiol Plant 127:551-560

Muñoz-Amatriaín M, Svensson JT, Castillo AM, Close TJ, Vallés MP (2009) Microspore embryogenesis: assignment of genes to embryo formation and green vs. albino plant production. Funct Integr Genomics 9:311-323

Pauk J, Puolimatka M, Tóth KL, Monostori T (2000) In vitro androgenesis of triticale in isolated microspore culture. Plant Cell Tissue Organ Cult 61:221-229

Pauk J, Mhaly R, Monostori T, Puolimatka M (2003) Protocol for triticale $(\times$ Triticosecale Wittmack $)$ microspore culture. In: Maluszynski M, Kasha KJ, Forster BP, Szarejko I (eds) Doubled haploid production in crop plants. A manual. Kluwer Academic Publishers, Dordrecht, pp 129-134

Reynolds TL, Kitto SL (1992) Identification of embryoid-abundant genes that are temporally expressed during pollen embryogenesis in wheat anther cultures. Plant Physiol 100:1744-1750

Reynolds TL, Crawford RL (1996) Changes in abundance of an abscisic acid-responsive, early cysteine-labeled metallothionein transcript during pollen embryogenesis in bread wheat (Triticum aestivum). Plant Mol Biol 32:823-829

Sánchez-Díaz RA, Castillo AM, Vallés MP (2013) Microspore embryogenesis in wheat: new markers genes for early, middle and late stages of embryo development. Plant Reprod. doi:10. 1007/s00497-013-0225-8
Savona S, Mattioli R, Nigro S, Falasca G, Della Rovere F, Cnstantino P, De Vries S, Ruffoni B, Trovato M, Altamura MM (2012) Two SERK genes are markers of pluripotency in Cyclamen persicum Mill. J Exp Bot 63:471-488

Soriano M, Li H, Boutilier K (2013) Microspore embryogenesis: establishment of embryo identity and pattern in culture. Plant Reprod. doi:10.1007/s00497-013-0226-7

Stephenson TJ, McIntyre L, Collet C, Xue G-P (2007) Genome-wide identification and expression analysis of the NF-Y family of transcription factors in Triticum aestivum. Plant Mol Biol 65:77-92

Tams SH, Melchinger AE, Bauer E (2005) Genetic similarity among European winter triticale elite germplasms assessed with AFLP and comparisons with SSR and pedigree data. Plant Breed 124:154-160

Tuvesson S, von Post R, Ljungberg A (2003) Triticale anther culture. In: Maluszynski M, Kasha KJ, Forster BP, Szarejko I (eds) Doubled haploid production in crop plants. A manual. Kluwer Academic Publishers, Dordrecht, pp 117-121

Tyrka M, Bednarek PT, Kilian A, Wedzony M, Hura T, Bauer E (2011) Genetic map of triticale compiling DArT, SSR, and AFLP markers. Genome 54:391-401

Vrinten PL, Nakamura T, Kasha KJ (1999) Characterization of cDNA expressed in the early stages of microspore embryogenesis in barley (Hordeum vulgare L.). Plant Mol Biol 41:455-463

Wang YY, Sun CS, Wang CC, Chien WI (1973) The induction of the pollen plantlets of Triticale and Capsicum annuum from anther culture. Sci Sin 16:147-151

Wang A, Xia Q, Xie W, Dumonceaux T, Zou J, Datla R, Selvaraj G (2002) Male gametophyte development in bread wheat (Triticum aestivum L.): molecular, cellular, and biochemical analyses of a sporophytic contribution to pollen wall ontogeny. Plant J 30:613-623

Wędzony M (2003) Protocol for doubled haploid production in hexaploid triticale $(\times$ Triticosecale Wittm.) by crosses with maize. In: Maluszynski M, Kasha KJ, Forster BP, Szarejko I (eds) Doubled haploid production in crop plants. A manual. Kluwer Academic Publishers, Dordrecht, pp 135-140

Worrall D, Ng CKY, Hetherington AM (2003) Sphingolipids, new players in plant signalling. Trends Plant Sci 8:317-320

Yang SL, Xie LF, Mao HZ, Puah CS, Yang WC, Jiang L, Sundaresan V, Ye D (2003) TAPETUM DETERMINANT 1 is required for cell specialization in the Arabidopsis anther. Plant Cell 15:2792-2804

Zhao T, Ni Z, Dai Y, Yao Y, Nie X, Sun Q (2006) Characterization and expression of 42 MADS-box genes in wheat (Triticum aestivum L.). Mol Genet Genomics 276:334-350

Żur I, Dubas E, Golemiec E, Szechyńska-Hebda M, Golebiowska G, Wedzony M (2009) Stress-related variation in antioxidative enzymes activity and cell metabolism efficiency associated with embryogenesis induction in isolated microspore culture of triticale ( $\times$ Triticosecale Wittm.). Plant Cell Rep 28:1279-1287

Żur I, Krzewska M, Dubas E, Golemiec E, Gołębiowska-Pikania G, Janowiak F, Stojałowski S (2012) Molecular mapping of loci associated with $\mathrm{ABA}$ accumulation in triticale $(\times$ Triticosecale Wittm.) anthers in response to low temperature stress inducing androgenic development. Plant Growth Regul 68:483-492 